HSTC Bulletin

Journal of the History of Canadian Science, Technology and Medecine

hstc

Revue d'histoire des sciences, des techniques et de la médecine au Canada

bulletin

\title{
Donors to the Cause
}

\section{Peter E. Greig}

Volume 4, numéro 1 (13), november 1979

URI : https://id.erudit.org/iderudit/1081846ar

DOI : https://doi.org/10.7202/1081846ar

Aller au sommaire du numéro

Éditeur(s)

HSTC Publications

ISSN

0228-0086 (imprimé)

1918-7742 (numérique)

Découvrir la revue

Citer ce document

Greig, P. E. (1979). Donors to the Cause. HSTC Bulletin, 4(1), 3-5.

https://doi.org/10.7202/1081846ar d'utilisation que vous pouvez consulter en ligne.

https://apropos.erudit.org/fr/usagers/politique-dutilisation/ 
occasionally, we receive more than orders for back issues. In this month's mail comes a cutting from the New York Times (Sunday, 9 September) sent by Bertrum Macdonald of the University of Western Ontario. This article, "Amateurs Who Act like Professionals," by Ronald Gross, describes some of the recent American scholarly activity that is parallel to the rise of our field of the history of Canadian science and technology. In history, especially, the amateur has long been active, but the nonprofessionals have made significant contributions in a number of disciplines. As Gross points out, several new fields such a psychohistory, have begun with the work of private scholars who eventually built up an infrastructure (Journals, publishing houses, etc.) by themselves. In other areas, amateurs have long been employed by professionals (e.g. astronomy and natural science). Gross quotes Prof. Robert stebbins, a sociologist at the University of Calgary, who believes that "Other fields have been benefiting for years from such amateur wings, .... [they] all use legions of nonprofessionals to help gather data. Why not us?" In our own field, the nonprofessional is probably the norm rather than the exception and we are uniquely placed to interact to both our benefits. Since there are so few professionals, we clearly have to build our own infrastructure together, and we professionals must lend a hand to the amateurs whenever we can, while being sustained by their enthusiasm.

$$
\text { * * * }
$$

Which brings us back to the problem of a home for 'Canadianists," discussed in HSTC \#11. On the initiative of Dr. G.R. Paterson, President of the Canadian Society of History and Philosophy of science, there is hope of bringing together the executives of CSHPS with those of the Canadian Society for History and Philosophy of Mathematics, and the Canadian Society for History of Medicine in a meeting in Ottawa, hopefully in January 1980. The purpose is to explore the possibility of some form of union or federation of the three societies, to increase efficiency and to encourage joint local events. Both CSHPS and CSHM have strong contingents of Canadianists. It might well be worth considering that if such a federation can be formed, that a fourth wing, devoted to our field, be formed within the larger umbrella group. This would allow for joint activity but also allow for autonomy and disciplinary initiatives.

DONORS TO THE CAUSE

The editors would like to thank the following for the generous contributions :

Bruce Sinclair Don Phillipson R.H. Estey 
Participants at the November 1978 Conference on the Study of Canadian History of Science and Technology resolved "That this Conference endorse the cooperation of its members with the Committee on Bibliographical Services for Canada, National Library, Ottawa, in an enquiry into the extent of bibliographical training and education in Canada, particularly in the fields of the history of Science and Technology and the encouragement of such education and training in Canada." This resolution was communicated to the Committee at its most recent meeting and the members of the Committee expressed their appreciation of the Conference's vote of confidence in their work.

In terms of bibliographical instruction the Committee is preparing a directory of courses in bibliography offered in Canada and developing an instructional package in bibliography for multidisciplinary use at the university (undergraduate and graduate) level.

An information kit outlining the objectives and activities of the Committee was prepared in April 1979. The kit contains a number of items which define the nature and promote the needs of bibliographical activity in Canada. All items will be regularly updated as required and new documents will be added to the kit from time to time. The kit presently contains:

- Committee on Bibliographical Services for Canada. 4 p. (outlines CBSC terms of reference, organization and activities from 1975 to 1978 )

- Committee on Bibliographical Services for Canada. Annual Report for the Fiscal Year 1978/79: Summary. 1 p.

- Visibility for Bibliography, by Francess G. Halpenny. 1 p.

- The Practice of Bibliography, by Francess G. Halpenny. 1 p.

- Education for Bibliograpy, by Francess G. Halpenny . 1 p.

- The Publishing of Canadian Bibliographies, by Anne B. Piternick. 2 p.

- Indexes and Abstracts: A Brief Discussion for Publishers, by Deborah C. Sawyer. folder

- Canadian Bibliographical Work in Progress: A Preliminary Subject Inventory. vii, $17 \mathrm{p}$.

- Canadian Bibliographies in Progress and the BCB. I p. (describes bibliographical activity inventory and its relationship with the Bibliography of Canadian Bibliographies/BCB

- Criteria for the Evaluation of Enumerative Bibliographies, by William F.E. Morley and Flora E. Patterson. 8 p.

With the exception of "Canadian Bibliographies in Progress: A Preliminary subject Inventory" all of the items in the kit are bilingual. 
Copies of the above items, individually or in kit form, are available free of charge from the Comnittee on Bibliographical services for Canada Secretariat, National Library of Canada, 395 Wellington St. Ottawa (ON) KIA ON4 -- (613) 995-3364.

Peter E. Greig

National Library of Canada

RECENT PUBLICATIONS RECENTES

Architecture :

J.-C. Dupont, ed. , Habitation rurale au Québec (Montréal, Hurtubise $\mathrm{HMH}, 1978$ ).

Biography:

Alex Inglis, Northern Vagabond: The Life and Career of J.B. Tyrrell--The Man Who Conquered the Canadian North (Toronto: Mcclelland and Stewart, 1978).

W.L. Morton, Henry Youle Hine, 1823-1908 (Toronto: University of Toronto Press, 1979).

Geology/Mining:

Walter 0. Kupsch, "From Erzgebirge to Cluff Lake-- a Scientific Journey through Time," The Musk-Ox No. 23 (Saskatoon: Institute of Northern Studies, 1978).

Institutions :

Norman T. Gridgeman, "A Semicentennial. The NRCC Research Journals 1929-1979"/"Un cinquantenaire. Les journaux de la recherche du CNRC 1929-1979," Canadian Journal of Microbiology (Apri1 1979).

Transportation:

Marilyn G. Miller, Straight Lines in Curved Space: Colonization Roads in Eastern Ontario (Toronto: Ministry of Culture and Recreation, 1979).

D. Murray Peden, Fall of an Arrow (Stittsville: Canada's Wings, 1979).

George Raudzens, The British Ordnance Department and Canada's Canals, 1815-1855 (Waterloo: Wilfrid Laurier University Press, 1979).

Science and Society:

William Leiss, Politics versus Ecology in Canada (Toronto: University of Toronto Press, 1979). 